\title{
Land Suitability for Ciplukan (Physalisangulata L.)Using Multicriteria Analysis
}

\author{
Nur Adliani ${ }^{*}$, Nirmawana Simarmata ${ }^{2}$ and Heriasnyah ${ }^{3}$ \\ ${ }^{1}$ Department of Pharmacy, Faculty of Science, Institut Teknologi Sumatera \\ ${ }^{2}$ Department of Geomatics Engineering, Faculty of Infrastructure and Regional, Institut Teknologi \\ Sumatera \\ ${ }^{3}$ Department of Electro Engineering, Faculty of Technology of Production and Industry, Institut \\ Teknologi Sumatera
}

\begin{abstract}
The study investigated the suitable land of Ciplukan (Physalisangulata L.), which is a source of medicine ingredient to lower the level of blood sugar. Ciplukan generally grows among wild plants. The objective of this research is to describe the characteristics of the land to grow ciplukan based on the land suitability. The class of land suitability is obtained by matching the physical character and chemistry from botanical garden land and overlaying appropriate maps with the requirements of growing ciplukan with ArcGIS. The class of suitability land acquired in the Botanical Gardens that earned the score of 6 to 8 is an area that does not suitable to cultivate the plants, with the size $52,189 \mathrm{Ha}$. The score of the lesser appropriate classification was of 9 to 11 with the size of area $180,966 \mathrm{Ha}$. The score of 12 has the size of area $49,111 \mathrm{Ha}$. The score of 12 fulfills 4 parameters. If all the land were suitable, then it would worth 3.9 to 11 . The parameters which were not corresponding at all is the value of score was 6 to 8 . The actual area at the Botanical Garden land was $80 \mathrm{Ha}$. So, some parts of the land can be used to grow ciplukan.
\end{abstract}

\section{Introduction}

The development of botanical garden leans on the effort to search for land suitability of growing plants in the botanical garden area. The land resource must be researched to determine its suitability with the plants in order to be productive and sustainable. Along with increasing market demand for Ciplukan (Physalisangulata L.), the land to grow Ciplukan (Physalisangulata L.) should be created to produce more number of Ciplukan (Physalisangulata L.). This will be a great contribution of ITERA, for there are many parts of ITERA botanical gardens which can be managed to cultivate ciplukan.

To grow Ciplukan (Physalisangulata L.) on suitable land requires data and information on potentials and land suitability. The assessment of land suitability class is based on the criteria of physical environment; in order that the land could be productive and sustainable $[1,2]$.

The objectives of this research are to: 1) determine class of land suitability; 2) determine characteristics of influential land for the development of Ciplukan (Physalisangulata L.); 3) find out optimal land based on the class of land suitability for the development of Ciplukan (Physalisangulata L.). 


\section{Materials and Method}

\subsection{Materials}

Research instruments used are computers with ArcGIS 9.3 and QM for software windows 3.0; printer; GPS; compass; ground drill, hoe, and shovel; plastic bags; camera; calculator and stationery as well other supporting equipment; map of the RBI Botanical Gardens; map of land; land use map; slope map; climatology data.

\subsection{Methods}

The researchwas conducted by preparing materials and research tools in the form of basic maps and data needed; combining slope maps and land maps; overlaying and usingArcGIS to get a unit map land; collecting data and carrying out field checks and observation of land conditions and measurements directly for determining sample points; taking soil samples based on land units for the laboratory analysis. To determine land quality and to classify the characteristics of quality of the land of each unit are done by comparing the quality and characteristics land $[3,4]$. To conduct land suitability assessment and to determine the classification of land suitability are executed by using ArcGIS based on soil biophysical properties data in the form of the characteristics of land and climate. Creating and describing suitable land maps contributes to grow Ciplukan (Physalisangulata L.) properly in the ITERA botanical garden. All chemicals used are analytical grade from Merck. 1-naphthylamine, 3,4dimethoxybenzaldehyde, methanol and acetone.

\section{Results and Discussions}

\section{Unit Land}

The overlay results on land suitability analysis were obtained by 6 land units. Maps that were overlaid in the form of soil type maps, slope maps and land use maps. These maps are used to get homogeneous land units that had similar soil types, slopes and land use.

\section{Land Suitability For Ciplukan Plants}

Based on observations in the field, most of the suitability class at the ITERA's Botanical Garden was class $S$ (according). This was indicated by the slope, land use, rainfall and the type of soil in the botanical garden. The suitability class was calculated by means of the scoring described in Table 1 .

\begin{tabular}{lll} 
Score & Classification & Area $(\mathrm{Ha})$ \\
\hline 12 & Corresponding & 49,111 \\
\hline 9 to 11 & Less Corresponding & 180,955 \\
\hline 6 to 8 & Not Corresponding & 52,189 \\
\hline
\end{tabular}

Table.1 Suitability Land Scoring

In addition, suitability land evaluation was to compare the requirements requested by the type of land use to be applied, with the properties or quality of land owned by the land to be used. Land evaluation was carried out to determine the potential value of a land with a specific purpose such as determining suitable areas to make areas of medicinal plants in the ITERA region. As in Figure 1, there is information on the area that was suitable for the location of planting medicinal plants. 


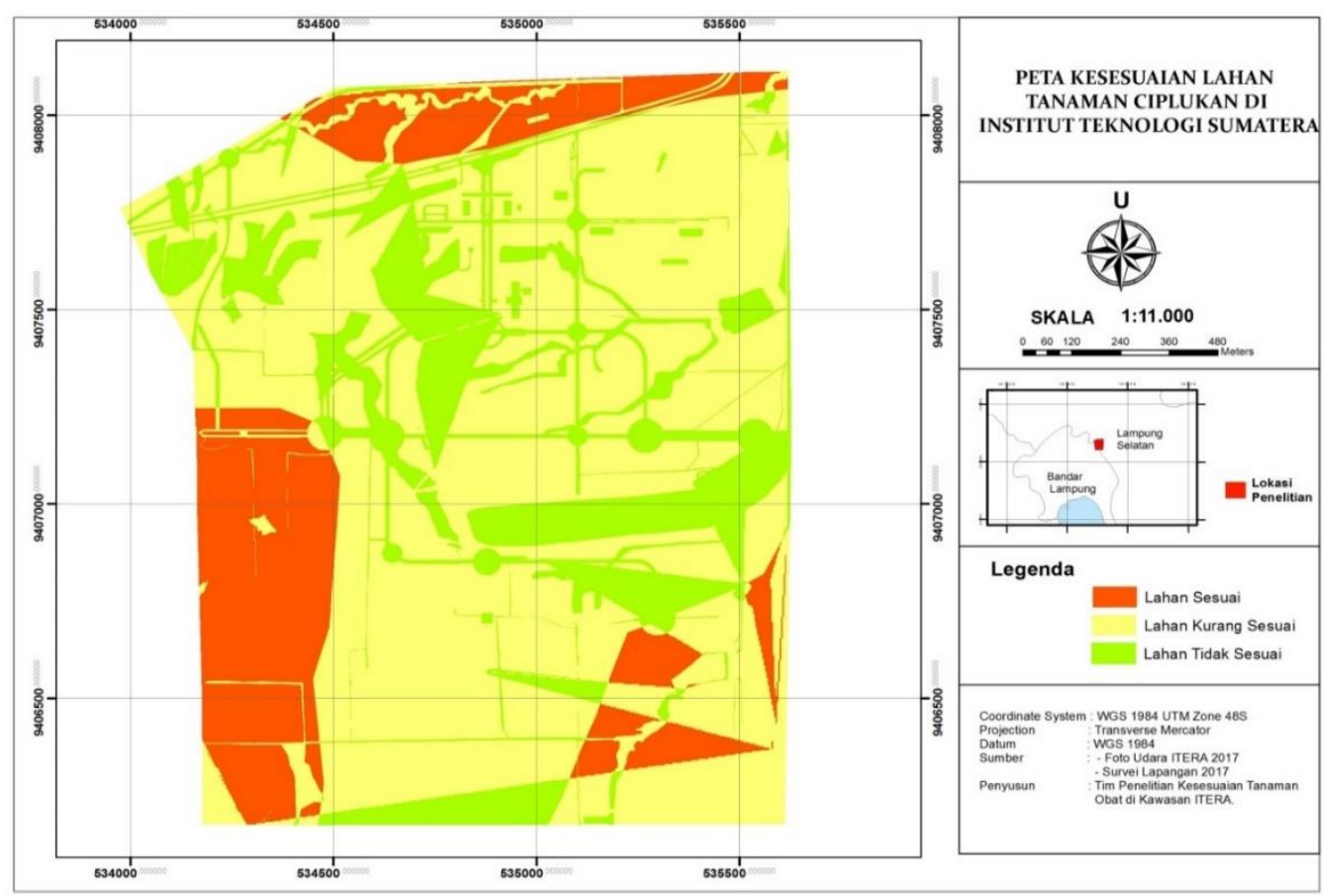

Fig. 1 Map of Conformity Plant Medication at ITERA

\section{Conclusion}

Thus, the class of suitability land acquired in the ITERA's Botanical Garden marked the score of 6 to 8 which means the area was not suitable to cultivate the plants and the size was $52.189 \mathrm{Ha}$. The score of less appropriate classification was of 9 to 11 to the area of $180.966 \mathrm{Ha}$. The score of 12 fulfills 4 parameters. For all the locations that are suitable, then they worth 3.9 to 11 each. Lastly, the parameters which are are not corresponding all, the score was 6 to8. The actual area at the ITERA's Botanical Garden land was $80 \mathrm{Ha}$. This means some parts of the land can be used to grow ciplukan.

\section{Reference}

[1] Emadi, M., Majid, B., Mojtaba, P., and Sayyed, A.K. An approach for land suitability evaluation using geostatistics, remote sensing, and geographic information system in arid and semiarid ecosystems. Volume 164, Issue 1-4, pp 501-511. 2010.

[2] FAO. A Framework for Land Evaluation. Soil Resources Management and Conservation Service Land and Water Development Division. Rome: FAO Soil Bulletin No. 32. FAOUNO. 1976.

[3] S. Drobne, D. A. Multi-attribute descision Analysis in GIS Weighted Linear Combination and Ordered Weighted Averaging. Informatica, 459-474. 2009.

[4] Joerin, F., Marius, T., and Andre, M. Using GIS and outranking multicriteria analysis for land-use suitability assessment. Vol. 15 (2). 2001.

\section{Acknowledgments}

This research was supported by Ministry of Research, Technology and Higher Education of the Republic of Indonesia who provided insight and expertise that greatly assisted the research. 